\title{
Libertarian Paternalism Is Not an Oxymoron
}

\section{Citation}

Richard H. Thaler \& Cass R. Sunstein, Libertarian Paternalism Is Not an Oxymoron, 70 U. Chi. L. Rev. 1159 (2003).

\section{Published Version}

http://chicagounbound.uchicago.edu/public_law_and_legal_theory/185/

\section{Permanent link}

http://nrs.harvard.edu/urn-3:HUL.InstRepos:13015053

\section{Terms of Use}

This article was downloaded from Harvard University's DASH repository, and is made available under the terms and conditions applicable to Other Posted Material, as set forth at http:// nrs.harvard.edu/urn-3:HUL.InstRepos:dash.current.terms-of-use\#LAA

\section{Share Your Story}

The Harvard community has made this article openly available.

Please share how this access benefits you. Submit a story.

Accessibility 


\section{University of Chicago Law School Chicago Unbound}

Public Law and Legal Theory Working Papers

Working Papers

2003

\section{Libertarian Paternalism Is Not an Oxymoron}

Richard H. Thaler

Cass R. Sunstein

Follow this and additional works at: http://chicagounbound.uchicago.edu/ public_law_and_legal_theory

Part of the Law Commons

\section{Recommended Citation}

Richard H. Thaler \& Cass R. Sunstein, "Libertarian Paternalism Is Not an Oxymoron" (Public Law \& Legal Theory Working Papers No. 43, 2003).

This Working Paper is brought to you for free and open access by the Working Papers at Chicago Unbound. It has been accepted for inclusion in Public Law and Legal Theory Working Papers by an authorized administrator of Chicago Unbound. For more information, please contact unbound@law.uchicago.edu. 


\section{CHICAGO}

Public LaW and Legal Theory Working Paper No. 43

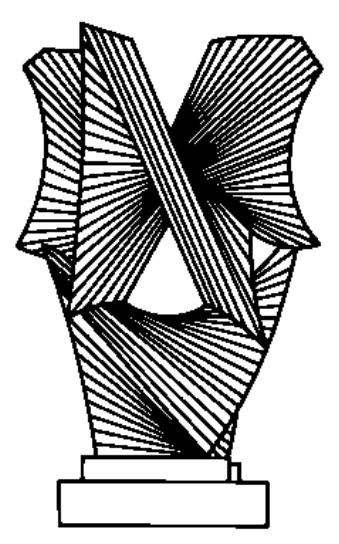

\section{LIBERTARIAN PATERNALISM IS NOT AN OXYMORON}

Cass R. Sunstein and Richard H. Thaler

THE LAW SCHOOL

THE UNIVERSITY OF CHICAGO

May 2003

This paper can be downloaded without charge at http://www.law.uchicago.edu/academics/publiclaw/index.html and at The Social Science Research Network Electronic Paper Collection: http://ssrn.com/abstract_id $=405940$ 
Preliminary draft 4/3/03

Forthcoming University of Chicago Law Review

All rights reserved

\title{
Libertarian Paternalism Is Not an Oxymoron
}

\author{
Cass R. Sunstein ${ }^{*}$ and Richard H. Thaler ${ }^{* *}$
}

\begin{abstract}
The idea of libertarian paternalism might seem to be an oxymoron, but it is both possible and legitimate for private and public institutions to affect behavior while also respecting freedom of choice. Often people's preferences are ill-formed, and their choices will inevitably be influenced by default rules, framing effects, and starting points. In these circumstances, a form of paternalism cannot be avoided. Equipped with an understanding of behavioral findings of bounded rationality and bounded self-control, libertarian paternalists should attempt to steer people's choices in welfare-promoting directions without eliminating freedom of choice. It is also possible to show how a libertarian paternalist might select among the possible options and to assess how much choice to offer. Examples are given from many areas, including savings behavior, labor law, and consumer protection.
\end{abstract}

\section{Introduction}

Consider two studies of savings behavior:

1. Hoping to increase savings by workers, several employers have adopted a simple strategy. Instead of asking workers to elect to participate in a 401(k) plan, workers will be assumed to want to participate in such a plan, and hence they will be automatically enrolled unless they specifically choose otherwise. This simple change in the default rule - from nonenrollment to enrollment -has produced dramatic increases in enrollment. ${ }^{1}$

\footnotetext{
${ }^{*}$ Karl N. Llewellyn Distinguished Service Professor, Law School and Department of Political Science, University of Chicago.

** Robert P. Gwinn Professor of Economics and Behavioral Science, University of Chicago Graduate School of Business. We are grateful to Richard Epstein, Carolyn Frantz, Robert Hahn, Howard Kunreuther, Owen Lamont, Bridget Madrian, Jane Mansbridge, Eric Posner, Richard Posner, Matthew Rabin, and David Strauss for valuable comments on a previous draft. We are also grateful to Caryn Campbell for excellent research assistance and to participants in seminars at the John F. Kennedy School of Government at Harvard University and at a work-in-progress lunch at the University of Chicago Law School; thanks too to discussants on a panel in which an early version of this paper was presented at the 2003 meetings of the American Economic Association.

${ }^{1}$ Brigette Madrian and Dennis Shea, The Power of Suggestion: Inertia in 401(k) Participation and Savings Behavior, 116 Quarterly Journal of Economics 1149 (2001); James Choi et al., Defined Contribution
} 
2. Rather than changing the default rule, some employers have provided their employees with a novel option: Allocate a portion of their future wage increases to savings. Employees who choose this plan are free to opt out at any time. A large number of employees have agreed to try the plan, and only a few have opted out. The result has been to produce significant increases in savings rates. ${ }^{2}$

Libertarians embrace freedom of choice, and so they deplore paternalism. ${ }^{3}$ Paternalists are thought to be deeply skeptical of freedom of choice and to deplore libertarianism. ${ }^{4}$ According to the conventional wisdom, libertarians cannot possibly embrace paternalism. The idea of libertarian paternalism seems to be a contradiction in terms.

Generalizing from the two studies just described, we intend to unsettle the conventional wisdom here. We elaborate a form of paternalism, libertarian in spirit, that should be acceptable to those who are firmly committed to freedom of choice on grounds of either autonomy or welfare. ${ }^{5}$ Indeed, we urge that libertarian paternalism provides a basis for both understanding and rethinking a number of areas of contemporary law, including those aspects that deal with worker welfare, consumer protection, and the family. ${ }^{6}$ In the process of defending these claims, we intend to make some objections to widely held beliefs about both freedom of choice and paternalism. ${ }^{7}$ Our emphasis is on

Pensions: Plan Rules, Participant Decisions, and the Path of Least Resistance, in James M. Poterba, ed., 16 Tax Policy and the Economy 67 (2002).

${ }^{2}$ Richard H. Thaler and Shlomo Benartzi, Save More Tomorrow: Using Behavioral Economics to Increase Employee Saving, Journal of Political Economy (forthcoming 2003).

${ }^{3}$ See, e.g., David Boaz, Libertarianism: A Primer (1998).

${ }^{4}$ See, e.g., Robert Goodin, Permissible Paternalism: In Defense of the Nanny State, 1 The Responsive Community 42 (1991).

${ }^{5}$ A very brief companion essay, intended for an economic audience and not dealing with law, investigates some of the issues explored here. See Richard H. Thaler and Cass R. Sunstein, Libertarian Paternalism, Am Econ Rev (forthcoming).

${ }^{6}$ Our defense of libertarian paternalism is closely related to the arguments for "asymmetrical paternalism," illuminatingly discussed in Colin Camerer, Samuel Issacharoff, George Loewenstein, Ted O'Donoghue, and Matthew Rabin, Regulation for Conservatives: Behavioral Economics and the Case for Asymmetric Paternalism (unpublished draft, 2002). Camerer et al. urge that governments should consider a weak form of paternalism, a form that attempts to help those who make mistakes, while imposing minimal costs on those who are fully rational. Our paper, written in parallel, has similar motivations, though libertarian paternalism may or may not be asymmetric in the sense identified by Camerer and his coauthors.

${ }^{7}$ See, e.g., Dennis Thompson, Political Ethics and Public Office 154-5 (1990), which lists three criteria for justified paternalism: impaired judgment, temporary and reversible intervention, and preventing a serious 
the fact that in many domains, people lack clear, stable, or well-ordered preferences. What they choose is a product of framing effects, starting points, and default rules, leaving the very meaning of the term "preferences" unclear.

Consider the question whether to undergo a risky medical procedure. When people are told, "Of those who have this procedure, 90 percent are alive after five years," they are far more likely to agree to the procedure than when they are told, "Of those who have this procedure, 10 percent are dead after five years. ${ }^{\prime 8}$ What, then, are the patient's "preferences" with respect to this procedure? Experience might be expected to solve this problem, but doctors too are vulnerable to this framing effect. ${ }^{9}$ Or return to the question of savings for retirement. It is now clear that if an employer requires employees to make an affirmative election in favor of savings, with the default rule devoting 100 percent of wages to current income, the level of savings will be far lower than if the employer adopts an automatic enrollment program, from which employees are freely permitted to opt out. ${ }^{10}$ Can workers then be said to have well-defined preferences about how much to save? This simple example can be extended to many situations involving the behavior of workers and consumers.

As the savings problem illustrates, the design features of both legal and organizational rules have surprisingly powerful influences on the choices made by those affected. We urge that such rules should be chosen with the explicit goal of improving the welfare of the people affected by them. The libertarian aspect of our strategies lies in the straightforward insistence that in general, people should be free to opt out of specified arrangements if they choose to do so. Hence we do not aim to defend any approach that blocks individual choices. The paternalistic aspect consists in the claim that it is legitimate for private and public institutions to attempt to influence people's behavior even when third party effects are absent. In other words, we argue for self-conscious efforts, by private and public institutions, to steer people's choices in directions that will improve their own welfare. In our understanding, a policy therefore counts as

and irreversible harm. We think that this account points in many sensible directions, but it neglects the inevitable effects of default rules, starting points, and framing effects on choices.

${ }^{8}$ See Donald Redelmeier, Paul Rozin, and Daniel Kahneman, Understanding Patients' Decisions, 270 JAMA 72, 73 (1993).

${ }^{9}$ Id.

${ }^{10}$ See below for details. 
"paternalistic" if it attempts to influence the choices of affected parties in a way that will make choosers better off. ${ }^{11}$ Drawing on some well-established findings in behavioral economics and cognitive psychology, we emphasize the possibility that in some cases individuals make inferior decisions in terms of their own welfare -- decisions that they would change if they had complete information, unlimited cognitive abilities, and no lack of willpower. ${ }^{12}$ In fact the notion of libertarian paternalism might be complemented by that of libertarian benevolence, by which starting points, framing effects, and default rules are enlisted in the interest of vulnerable third parties, and we shall devote some discussion to this possibility.

Libertarian paternalism is a relatively weak and nonintrusive type of paternalism, because choices are not blocked or fenced off. In its most cautious forms, libertarian paternalism imposes trivial costs on those who seek to depart from the planner's preferred option. But the approach we recommend nonetheless counts as paternalistic, because private and public planners are not trying to track people's anticipated choices, but are self-consciously attempting to move people in directions that will promote their welfare. Some libertarians are likely to have little or no trouble with our endorsement of paternalism for private institutions; their chief objection is to paternalistic law and government. But as we shall show, the same points that support welfare-promoting private paternalism apply to government as well. It follows that one of our principal targets is the dogmatic anti-paternalism of numerous analysts of law, including many economists and economically oriented lawyers. We believe that this dogmatism is based on a combination of a false assumption and two misconceptions. ${ }^{13}$

The false assumption is that almost all people, almost all of the time, make choices that are in their best interest or at the very least are better, by their own lights,

\footnotetext{
${ }^{11}$ For a similar definition, see Donald VanDeVeer, Paternalistic Intervention 22 (1986).

${ }^{12}$ Bounded rationality and bounded will-power are described in Christine Jolls et al., A Behavioral Approach to Law and Economics, 50 Stan L Rev. 1471, 1477-79 (1998).

${ }^{13}$ See, e.g., Richard Epstein, In Defense of the Contract At Will, 51 U Chi L Rev 947 (1984). For a similar complaint, see Ted O'Donoghue and Matthew Rabin, Studying Optimal Paternalism, As Illustrated by a Model of Sin Taxes, Am. Econ. Rev. (forthcoming 2003): [E]conomists deserve to be taken seriously in some policy debates only if we get more serious about notions of when and how people do and don't pursue their own best interests. To best contribute to debates over regulating private financial decisions, we should study when financial decisions are based on fallacious statistical reasoning and study when selfcontrol problems lead people to borrow too heavily; to best contribute to debates over teenage smoking, we
} 
than the choices that would be made by third parties. This claim is either tautological, and therefore uninteresting, or testable. We claim that it is testable and false, indeed obviously false. Indeed we do not believe that anyone believes it on reflection. Suppose that a chess novice were to play a game of chess against an experienced player. Predictably the novice would lose precisely because he made inferior choices, choices that could easily be improved by some helpful hints. More generally, how well people choose is an empirical question, one whose answer is likely to vary across domains. ${ }^{14}$ As a first approximation, it seems reasonable to say that people make better choices in contexts in which they have experience and good information (say, choosing ice-cream flavors) than in contexts in which they are inexperienced and ignorant (say, choosing among medical treatments or investment options). So long as people are not choosing perfectly, it is at least possible that some policy could make them better off by improving their decisions.

The first misconception is that there are viable alternatives to paternalism. In many situations, some organization or agent must make a choice that will affect the behavior of some other people. There is, in those situations, no alternative to a kind of paternalism -- at least in the form of an intervention that affects what people choose. We are emphasizing, then, the possibility that people's preferences, in certain domains and across a certain range, do not predate the choices made by planners. ${ }^{15}$ The point applies to both private and public actors, and hence to those who design legal rules as well as to those who serve consumers. As a simple example, consider the cafeteria at some organization. The cafeteria must make a multitude of decisions, including which foods to

ought to consider reasons to believe that teenagers might become smokers against their own long-run best interest."

${ }^{14}$ In some areas, of course, it will be difficult to reach uncontroversial conclusions on the basis of empirical study alone, because contested judgments of value are in the background. Do people choose well if they choose to marry young, or do they choose better if they cohabit for a long time before marrying? Do young, unmarried women choose well if they choose abortion? Empirical issues are highly relevant here, but they will hardly resolve all social disputes on these questions. We are not attempting to say anything controversial about welfare here, or to take sides in reasonable disputes about how to understand that term. For discussion, see Amartya Sen, Development As Freedom (1999); Well-Being: The Foundations of Hedonic Psychology (Daniel Kahneman et al. eds. 1998).

${ }^{15}$ For claims to this effect, see Russell Korobkin, The Status Quo Bias and Contract Default Rules, 83 Cornell L. Rev. 608 (1998); Cass R. Sunstein, Endogenous Preferences, Environmental Law, 22 J. Legal Stud. 217 (1993). Important qualifications come from Robert Ellickson, Order Without Law (1992), discussing settings in which people organize their affairs without reference to law. But even with those 
serve, which ingredients to use, and in what order to arrange the choices. Suppose that the director of the cafeteria notices that its customers have a tendency to choose more of the items that are presented earlier in the line. How should the director decide in what order to present the items? To simplify, consider some alternative strategies that the director might adopt in deciding which items to "feature" early in the line:

1. She could make choices that she thinks would make the customers best off, all things considered.

2. She could make choices at random.

3. She could choose those items that she thinks would make the customers as obese as possible.

4. She could give consumers what she thinks they would choose on their own.

Option 1 appears to be paternalistic, but would anyone advocate options 2 or 3 ? Option 4 is what anti-paternalists would favor, but it is much harder to implement than it might seem. Across a certain domain of possibilities, consumers will often lack wellformed preferences, in the sense of preferences that are firmly held and preexist the directors' own choices about how to order the relevant items. If the arrangement of the alternatives has a significant effect on the selections the customers make, then their true "preferences" do not formally exist.

Of course market pressures will impose a discipline on the choices of cafeteria directors, and to that extent, those directors must indeed provide people with what they want. A cafeteria who faces competition and offers healthy but terrible-tasting food is unlikely to do well. But some of the time, market success will come not from tracking people's ex ante preferences, but from providing goods and services that turn out, in practice, to promote their welfare, all things considered. Consumers might be surprised by what they end up liking; indeed, their preferences might change as a result of consumption. ${ }^{16}$ And in some cases, the discipline imposed by market pressures will nonetheless allow the director a great deal of room to maneuver, because people's preferences are not well-formed across the relevant domains.

qualifications, there is no objection to libertarian paternalism; in the contexts explored by Ellickson, the default rule is irrelevant, not harmful.

${ }^{16}$ See Gary Becker, Accounting for Tastes (1997). 
Some libertarians will happily accept this point for private institutions. Their objection will be to government efforts to reject choice in the name of welfare. Skepticism about government might be based on the fact that governments are disciplined less or perhaps not at all by market pressures. Or such skepticism might be based on the fear that parochial interests will drive government in their preferred directions (the public choice problem ${ }^{17}$ ). We agree that for government, the risks of mistake and overreaching are real and sometimes serious. But governments, no less than cafeterias (which governments frequently run), have to provide starting points of one or another kind; this is not avoidable. As we shall emphasize, they do so every day through the rules of contract and tort, in a way that inevitably affects some preferences and choices. ${ }^{18}$ In this respect, the antipaternalist position is unhelpful, a literal nonstarter.

The second misconception is that paternalism always involves coercion. As the cafeteria example illustrates, the choice of the order in which to present food items does not coerce anyone to do anything, yet one might prefer some orders to others on grounds that are paternalistic in the sense that we understand the term. Would anyone object to putting the fruit and salad before the desserts at an elementary school cafeteria if the result was to increase the consumption ratio of apples to Twinkies? Is this question fundamentally different if the customers are adults? Since no coercion is involved, we think that some types of paternalism should be acceptable to even the most ardent libertarian. In the important domain of savings behavior, we shall offer a number of illustrations. To those antilibertarians who are suspicious of freedom of choice and would prefer to embrace welfare instead, we urge that it is often possible for paternalistic planners to make common cause with their libertarian adversaries, by adopting policies that promise to promote welfare but that also make room for freedom of choice. To confident planners, we suggest that the risks of confused or ill-motivated plans are reduced if people are given the opportunity to reject the planner's preferred solutions.

The thrust of our argument is that the term paternalistic should not be considered pejorative, just descriptive. Once it is understood that some organizational decisions are inevitable, that a form of paternalism cannot be avoided, and that the alternatives to

\footnotetext{
${ }^{17}$ For a classic illustration, see Bruce A. Ackerman and William T. Hassler, Clean Coal/Dirty Air (1983).
} 
paternalism (such as choosing options to make people worse off) are unattractive, we can abandon the less interesting question of whether to be paternalistic or not, and turn to the more constructive question of how to choose among the possible choice-influencing options. To this end we make two general suggestions about how to think about these problems. First, programs should be designed using a type of cost-benefit analysis, one in which a serious attempt is made to measure the costs and benefits of outcomes (rather than estimates of willingness to pay). Choosers should be given more choices if the benefits exceed the costs. Second, some results from the psychology of decision making should be used to provide some ex ante guidelines to support reasonable judgments about when consumers will gain most by choosing for themselves. We argue that those who are generally inclined to oppose paternalism should consider these suggestions uncontroversial.

The remainder of this Article is organized as follows. In Part II, we briefly support the claim that people's choices might not promote their own welfare. Part III, in some ways the conceptual heart of the Article, asks whether a form of paternalism is inevitable. We suggest that because of the likely effects of default rules, framing effects, and starting points on choices and preferences, paternalism, at least in a weak sense, is impossible to avoid. To be sure, planners can try to avoid paternalism by coercing people to make choices, but sometimes people will resist that coercion (which is along one dimension paternalistic too, simply because people sometimes do not want to choose). Part IV investigates how a libertarian paternalist might select among the major options, including minimal paternalism, coerced choices, procedural constraints, and substantive constraints. Part V explores a large question: How much choice should be offered? We identify a set of questions that must be answered in order to know people's welfare is likely to be promoted or instead undermined by a large option set. Part VI explores objections.

\footnotetext{
${ }^{18}$ See Russell Korobkin, The Status Quo Bias and Contract Default Rules, 83 Cornell L. Rev. 608 (1998).
} 


\section{The Rationality of Choices}

The presumption that individual choices should be respected is usually based on the claim that people do an excellent job of making choices, or at least that they do a far better job than third parties could possibly do. ${ }^{19}$ As far as we can tell, there is little empirical support for this claim, at least if it is offered in this general form. Return to the issue of obesity. Rates of obesity in the United States are now approaching 20 percent and over 60 percent of Americans are considered either obese or overweight. ${ }^{20}$ There is overwhelming evidence that obesity causes serious health risks, frequently leading to premature death. ${ }^{21}$ It is quite fantastic to suggest that everyone is choosing the optimal diet, or a diet that is preferable to what might be produced with third party interference. Of course rational people care about the taste of food, not simply about health, but the claim that Americans are choosing diets optimally would be hard to support. What is true

${ }^{19}$ It is usually, but not always, based on this assumption. Some of the standard arguments against paternalism rest not on consequences but on autonomy - on a belief that people are entitled to make their own choices even if they err. Thus John Stuart Mill, On Liberty, in John Stuart Mill, Utilitarianism, On Liberty, Considerations on Representative Government 73 (H.B. Acton ed. 1972), is a mix of autonomybased and consequentialist claims. Our principal concern here is with welfare and consequences, though as we suggest below, freedom of choice is sometimes an ingredient in welfare. We do not disagree with the view that autonomy has claims of its own, but we believe that it would be fanatical, in the settings that we discuss, to treat autonomy, in the form of freedom of choice, as a kind of trump, not to be overridden on consequentialist grounds. In any case the autonomy argument is undermined by the fact, discussed in section II, that sometimes preferences and choices are a function of given arrangements. Most important, we think that respect for autonomy is adequately accommodated by the libertarian aspect of libertarian paternalism, as discussed below.

We note as well that the complex relationship between preferences, choices, and autonomy is a large theme in the liberal tradition. See Jon Elster, Sour Grapes (1983); Don Herzog, Happy Slaves (1989). Sometimes it is emphasized that preferences and choices are a product of unjust background conditions, jeopardizing autonomy, and that when choices are a product of background injustice, respect for those choices need not promote autonomy. See Amartya Sen, Commodities and Capabilities (1986). Our discussion does not engage these issues, but there is a clear connection between such arguments, and claims about "adaptive preferences," see Elster, supra, and our emphasis on status quo bias and the endowment effect. See below.

${ }^{20} \mathrm{http} / / /$ www.cdc.gov/nccdphp/dnpa/obesity/trend/maps/. This represents a 61 percent increase in obesity between 1991 and 2000; 38.8 million Americans qualify as obese. See also AH Mokdad et al., The continuing epidemics of obesity and diabetes in the United States, 286 JAMA 1195 (2001) (discussing increase in obesity).

${ }^{21}$ See, e.g., E.E. Calle et al. Body-mass Index and Mortality in a Prospective Cohort of U.S. adults, 341 New England Journal of Medicine 1095 (1999). According to the federal government, "Approximately 280,000 adult deaths in the United States each year are related to obesity. Several serious medical conditions have been linked to obesity, including type 2 diabetes, heart disease, high blood pressure, and stroke. Obesity is also linked to higher rates of certain types of cancer. Obese men are more likely than non-obese men to die from cancer of the colon, rectum, or prostate. Obese women are more likely than 
for diets is true as well for much other risk-related behavior, including smoking and drinking, which produce over 500,000 premature deaths each year. ${ }^{22}$ In these circumstances, people's choices cannot reasonably be thought, in all domains, to maximally promote their well-being.

On a more scientific level, research by psychologists and economists over the past three decades has raised questions about the rationality of many judgments and decisions that individuals make. People fail to make forecasts that are consistent with Bayes' rule, ${ }^{23}$ use heuristics that lead them to make systematic blunders, ${ }^{24}$ exhibit preference reversals (that is, they prefer $\mathrm{A}$ to $\mathrm{B}$ and $\mathrm{B}$ to $\mathrm{A}$ ), ${ }^{25}$ suffer from problems of self-control, ${ }^{26}$ and make different choices depending on the wording of the problem. ${ }^{27}$ It is possible to raise questions about some of these findings and to think that people may do a better job of choosing in the real world than they do in the laboratory. But studies of actual choices reveal many of the same problems, even when the stakes are high. ${ }^{28}$

\footnotetext{
non-obese women to die from cancer of the gallbladder, breast, uterus, cervix, or ovaries." See http://www.niddk.nih.gov/health/nutrit/pubs/unders.htm\#Healthrisks.

${ }^{22}$ See Cass R. Sunstein, Risk and Reason 8-9 (2002). For an interesting discussion, see Jonathan Gruber, Smoking's "Internalities," Regulation 52 (Winter 2002-2003).

${ }^{23}$ See David Grether, Bayes' Rule as a Descriptive Model: The Representativeness Heuristic, 95 Quarterly Journal of Economics 537 (1980).

${ }^{24}$ See, e.g., Amos Tversky and Daniel Kahneman, Availability: A Heuristic for Judging Frequency and Probability, 5 Cog Psych 207 (1973); Amos Tversky and Daniel Kahneman, Judgment under Uncertainty: Heuristics and Biases, 185 Science 1124 (1974); Daniel Kahneman and Shane Frederick, Representativeness Revisited: Attribute Substitution in Intuitive Judgment in Heuristics and Biases; The Psychology of Intuitive Judgment 49 (Thomas Gilovich et al. eds. 2002).

${ }^{25}$ See Richard Thaler, The Winner's Curse 79-91 (1992); in the legal context, see Cass R. Sunstein, Daniel Kahneman, David Schkade, and Ilana Ritov, Predictably Incoherent Judgments, 54 Stan L Rev. 1153 (2002).

${ }^{26}$ Shane Frederick, Ted O’Donoghue and George Loewenstein, Time Discounting and Time Preference: A Critical Review , 40 Journal of Economic Literature 351 (2002).

${ }^{27}$ See Colin Camerer, Prospect Theory in the Wild, in Choices, Values, and Frames 294-95 (Daniel Kahneman and Amos Tversky eds. 2000); Eric Johnson et al., Framing, Probability Distortions, and Insurance Decisions, in id. at 224, 238.

${ }^{28}$ For evidence that heuristics and biases operate in the real world, even when dollars are involved, see Werner F. M. De Bondt and Richard H. Thaler, Do Security Analysts Overreact? 80 American Economic Review 52 (1990) ; Robert Shiller, Irrational Exuberance 136-147 (2000) (discussing anchoring and overconfidence in market behavior); Colin Camerer and Robin Hogarth, The Effects of Financial Incentives in Experiments, 19 J. Risk and Uncertainty 7 (1999), which finds that financial incentives have never eliminated anomalies or persistent irrationalities. See also Colin Camerer, Behavioral Game Theory 60-62 (2003), finding little effects from increased stakes in ultimatum games (designed to test the hypothesis that people are self-interested), and adding: "If I had a dollar for every time an economist claimed that raising the stakes would drive ultimatum behavior toward self-interest, I'd have a private jet on standby all day." Id. at 60.
} 
We do not intend to outline all of the relevant evidence here, but consider an illustration from the domain of savings behavior. Benartzi and Thaler investigate how much investors like the portfolios they have selected in their defined contribution savings plans. ${ }^{29}$ Employees volunteered to share their portfolio choices with the investigators (by bringing a copy of their most recent statement to the lab). They were then shown the probability distributions of expected retirement income for three investment portfolios simply labeled A, B and C. Unbeknownst to the subjects, the three portfolios were their own and portfolios mimicking the average and median choices of their fellow employees. The distributions of expected returns were computed using the software of Financial Engines, the financial information company founded by William Sharpe. On average, the subjects rated the average portfolio equally with their own portfolio, and judged the median portfolio to be significantly more attractive than their own. ${ }^{30}$ Indeed, only 20 percent of the subjects preferred their own portfolio to the median portfolio. ${ }^{31}$ Apparently, people do not gain much, by their own lights, from choosing investment portfolios for themselves.

Or consider people's willingness to take precautions. In general, the decision to buy insurance for natural disasters is a product not of a systematic inquiry into either costs and benefits, but of recent events. ${ }^{32}$ If floods have not occurred in the immediate past, people who live on flood plains are far less likely to purchase insurance. ${ }^{33}$ In the aftermath of an earthquake, the level of insurance for earthquakes rises sharply - but it declines steadily from that point, as vivid memories recede. ${ }^{34}$ Findings of this kind do not establish that people's choices are usually bad or that third parties can usually do better. But they do show that some of the time, people do not choose wisely even when the stakes are high.

It is true that people sometimes respond to their own bounded rationality, for example by hiring agents or by delegating decisions to others. ${ }^{35}$ It is also true that

\footnotetext{
${ }^{29}$ See Shlomo Benartzi and Richard Thaler, How Much is Investor Autonomy Worth?, 57 Journal of Finance 1593 (2002).

${ }^{30}$ Id.

${ }^{31}$ Id.

${ }^{32}$ Paul Slovic, The Perception of Risk 40 (2000).

${ }^{33} \mathrm{Id}$.

${ }^{34} \mathrm{Id}$.

${ }^{35}$ See Cass R. Sunstein and Edna Ullmann-Margalit, Second-Order Decisions, 110 Ethics 5 (1999).
} 
learning frequently occurs and enables people to overcome their own limitations. But many of the most important decisions people make (e.g., buying a home, choosing a spouse) are made infrequently and typically without the aid of impartial experts. The possibilities of delegation and learning are insufficient to ensure that people's choices always promote their welfare or that they always do better than third parties would. In any event our emphasis here is not on blocking choices, but on strategies that move people in welfare-promoting directions while also allowing freedom of choice. Evidence of bounded rationality, and of problems of self-control, is sufficient to suggest that such strategies are worth exploring. Of course many people value freedom of choice as an end in itself, but they should not object to approaches that preserve that freedom while also promising to improve people's lives. ${ }^{36}$

\section{Is Paternalism Inevitable?}

A few years ago, the tax law was changed so that employees could pay for employer-provided parking on a pre-tax basis. ${ }^{37}$ Previously, such parking had to be paid for with after-tax dollars. Our employer, and the employer of some of our prominent antipaternalistic colleagues, sent around an announcement of this change in the law, and adopted the following policy: Unless the employee notified the payroll department, deductions for parking would be taken from pre-tax rather than post-tax income. In other words, the University of Chicago decided that the default option would be to pay for parking with pre-tax dollars, but employees could opt out of this arrangement and pay with after-tax dollars. Call this choice Plan A. An obvious alternative, Plan B, would be to announce the change in the law and tell employees that if they want to switch to the new pre-tax plan they should return some form electing this option. The only difference between the two plans is the default. Under Plan A the new option is the default whereas under Plan B the status quo is the default. We will refer to the former as "opt-out" strategies and the latter as "opt-in" strategies.

\footnotetext{
${ }^{36}$ See note supra (discussing freedom of choice as part of autonomy).

${ }^{37}$ IRS Code Section 132(f).
} 
How should the university choose between opt-in and opt-out? In the specific parking example, it seems to be the case that every employee would prefer to pay for parking with pretax dollars rather than post-tax dollars. Since the cost savings are substantial (parking costs as much as $\$ 1200$ per year) and the cost of returning a form is trivial, standard economic theory predicts that the university's choice will not really matter. Under either plan, all employees would choose (either actively or by default under Plan A) the pretax option. In real life, however, had the university adopted Plan B, we suspect that many employees, especially faculty members (and probably including the present authors), would still have that form buried somewhere in their office and would be paying substantially more for parking on an after-tax basis. In short, the default plan would have had large effects on behavior. Throughout we shall be drawing attention to the effects of default plans on choices. Often those plans will be remarkably sticky.

\section{A. Savings and Employers}

1. Data. Our conjecture is supported by the outcome of numerous experiments documenting a "status quo" bias. ${ }^{38}$ The existing arrangement, whether set out by private institutions or by government, is often robust. One illustration of this phenomenon comes from studies of automatic enrollment in $401(\mathrm{k})$ employee savings plans, ${ }^{39}$ and we now elaborate the brief account with which we began. Most 401(k) plans use an opt-in design. When employees first become eligible to participate in the 401(k) plan, they receive some plan information and an enrollment form that must be completed in order to join. Under the alternative of automatic enrollment, employees receive the same information but are told that unless they opt out, they will be enrolled in the plan (with some default options for savings rates and asset allocation). In companies that offer a "match" (the employer matches the employee's contributions according to some formula, often a $50 \%$ match up to some cap), most employees eventually do join the plan, but enrollments occur much

\footnotetext{
${ }^{38}$ William Samuelson and Richard J. Zeckhauser, Status Quo Bias in Decision Making, 1 Journal of Risk and Uncertainty 7 (1988); Daniel Kahneman, Jack L. Knetsch, and Richard H. Thaler, The Endowment Effect, Loss Aversion, and Status Quo Bias, 5 Journal of Economic Perspectives 193 (1991).

${ }^{39}$ See Brigette Madrian and Dennis Shea, The Power of Suggestion: Inertia in 401(k) Participation and Savings Behavior, 116 Quarterly Journal of Economics 1149 (2001); James Choi et al., Defined
} 
sooner under automatic enrollment. For example, Madrian and Shea found that initial enrollments jumped from $49 \%$ to $86 \%,{ }^{40}$ and Choi et al. find similar results for other companies. $^{41}$

Should the adoption of automatic enrollment be considered paternalistic? And if so, should it be seen as a kind of officious meddling with employee preferences? We answer these questions yes and no respectively. If employers think (correctly we believe) that most employees would prefer to join the 401(k) plan if they took the time to think about it and did not lose the enrollment form, then by choosing automatic enrollment they are acting paternalistically by our definition of the term. They are attempting not to track the employee's ex ante preferences or to protect against harms to third parties, but to steer employees' choices in directions that will, in their view, promote employees' welfare. Since no one is forced to do anything, we think that this steering should be considered unobjectionable even to committed libertarians. The employer must choose some set of rules, and either plan affects employees' choices. No law of nature says that in the absence of an affirmative election by employees, 0 percent of earnings will go into a retirement plan. Because both plans alter choices, neither one can be said, more than the other, to count as a form of objectionable meddling.

2. Skeptics. Skeptical readers, insistent on freedom of choice, might be tempted to think that there is a way out of this dilemma. Employers could avoid choosing a default if they required employees to make a choice, either in or out. Call this option coerced choosing. Undoubtedly coerced choosing is attractive in some settings, but a little thought reveals that this is not at all a way out of the dilemma. On the contrary, coerced choosing is simply another option among many that the employer can elect. In fact the very requirement that employees make a choice has a strong paternalistic element. Many employees do not want to have to make a choice (and might make a second-order choice

Contribution Pensions: Plan Rules, Participant Decisions, and the Path of Least Resistance, in James M. Poterba, ed., 16 Tax Policy and the Economy, 67 (2002).

${ }^{40}$ See supra note.

${ }^{41}$ See supra note. In a separate phenomenon, the default rule also had a significant effect on the chosen contribution rate. See Madrian and Shea, supra note. The default contribution rate (3\%) tended to stick; a majority of employees maintained that rate even though this particular rate was chosen by less than $1 \%$ of employees hired before the automatic enrollment. Id. The same result was found for the default allocation of the investment: While less than $1 \%$ of employees chose a $100 \%$ investment allocation to the money market fund, a substantial majority of employees chose that allocation when it was the default rule. Id. 
not to have to do so). Why should employers force them to choose? Coerced choosing respects freedom of choice in a certain respect; but it does not appeal to those who would choose not to choose, and indeed it will seem irritating and perhaps unacceptably coercive by their lights. In any case an empirical question remains: What is the effect of forced choosing? Choi et al. find that coerced choosing increases enrollments relative to the opt-in rule, though by not as much as automatic enrollment. ${ }^{42}$ Our discussion in section IV below offers some suggestions about the circumstances in which it makes most sense to force people to choose.

Other skeptics might think that employers should avoid paternalism by doing what most employees would want employers to do. On this approach, a default rule can successfully avoid paternalism if it tracks employees' choices. Sometimes this is a plausible solution. But what if many or most employees do not have stable or wellformed preferences, and what if employee choices are inevitably a product of the default rule? In such cases, it is meaningless to ask what most employees would do. The choices employees will make depend on the way the employer frames those choices. Employee "preferences," as such, do not exist in those circumstances. We think that across a certain domain of reasonable possibilities, this is the situation with respect to savings. Of course most people would not like 99 percent of their income to go to savings, and no effort to frame choices is likely to lead people to choose to save at that level. But across a range of allocations, many employees lack well-forced preferences that are robust to different starting points.

\section{B. Government}

Some enthusiasts for free choice might be willing to acknowledge these points and hence to accept private efforts to steer people's choices in what seem to be the right directions. Market pressures, and the frequently wide range of possible options, might be thought to impose sufficient protection against objectionable steering. But our emphasis has been on the inevitability of paternalism, and on this count, the same points apply to some choices made by governments in establishing legal rules.

\footnotetext{
${ }^{42}$ See note supra.
} 
1. Default rules. Default rules of some kind are inevitable, and much of the time, those rules will affect preferences and choices. ${ }^{43}$ In the neglected words of a classic article, a "minimum of state intervention is always necessary. . . . When a loss is left where it falls in an auto accident, it is not because God so ordained it. Rather it is because the state has granted the injurer an entitlement to be free of liability and will intervene to prevent the victim's friends, if they are stronger, from taking compensation from the injurer. ${ }^{, 44}$ If the entitlement-granting rules seem invisible, and to be a simple way of protecting freedom of choice, it is because they appear so sensible and natural that they are not taken to be a legal allocation at all. But this is a mistake. What we add here is that when a default rule affects preferences and behavior, it is having the same effect as employer presumptions about savings plans. This effect is often significant. So long as people can contract around the default rule, it is fair to say that the legal system is protecting freedom of choice, and in that sense complying with libertarian goals.

Consumers, workers, and married people, ${ }^{45}$ for example, are surrounded by a network of legal allocations that provide the background against which agreements are made. As a matter of employment law, and consistently with freedom of contract, workers might be presumed subject to discharge "at will," or they might be presumed to be protected by an implied right to be discharged only "for cause." They might be presumed to have a right to vacation time, or not. They might be presumed to be protected by safety requirements, or the employer might be free to invest in safety as he wishes, subject to market pressures. In all cases, the law must establish whether workers have to "buy" certain rights from employers or vice versa. ${ }^{46}$ Legal intervention, in this important sense, cannot be avoided. The same is true for consumers, spouses, and all others who are involved in legal relationships. Much of the time, the legal background matters, even if transactions costs are zero, because it affects choices and preferences. ${ }^{47}$ Here, as in the private context, a form of paternalism is unavoidable.

\footnotetext{
${ }^{43}$ See Korobkin, supra note; Cass R. Sunstein, Switching the Default Rule, 77 New York University Law Review 106 (2002).

${ }^{44}$ Guido Calabresi and A. Douglas Melamed, Property Rules, Liability Rules, and Inalienability: One View of the Cathedrawl, 85 Harv L Rev 1089, 1090-91 (1972).

${ }^{45}$ On marriage and legal rules, see Susan Moller Okin, Justice, Gender, and the Family (1989).

${ }^{46}$ See Cass R. Sunstein, Human Behavior and the Law of Work, 87 Va L Rev 205, 208-12 (2001).

${ }^{47}$ See the demonstrations in Kahneman, Knetsch, and Thaler, supra note; Korobkin, supra note.
} 
In the context of insurance, an unplanned, natural experiment showed that the default rule can be very "sticky." 48 New Jersey created a system in which the default insurance program for motorists included a relatively low premium and no right to sue; purchasers were allowed to deviate from the default program and to purchase the right to sue by choosing a program with that right and also a higher premium. By contrast, Pennsylvania offered a default program containing a full right to sue and a relatively high premium; purchasers could elect to switch to a new plan by "selling" the more ample right to sue and paying a lower premium. In both cases, the default rule tended to stick. A strong majority accepted the default rule in both states, with only about $20 \%$ of New Jersey drivers acquiring the full right to sue, and $75 \%$ of Pennsylvanians retaining that right. ${ }^{49}$ There is no reason to think that the citizens of Pennsylvania have systematically different preferences from the citizens of New Jersey. The default plan is what produced the ultimate effects. And indeed controlled experiments find the same results, showing that the value of the right to sue is much higher when it is presented as part of the default package. $^{50}$

In another example, a substantial effect from the legal default rule was found in a study of second-year and third-year law student reactions to different state law provisions governing vacation time from firms. ${ }^{51}$ The study was intended to be reasonably realistic, involving as it did a pool of subjects to whom the underlying issues were hardly foreign. Advanced law students have devoted a good deal of time to thinking about salaries, vacation time, and the tradeoffs among them. The study involved two conditions. In the first, state law guaranteed two weeks of vacation time, and students were asked to state their median willingness to pay (in reduced salary) for two extra weeks of vacation. ${ }^{52}$ In this condition, the median willingness to pay was $\$ 6000$. In the second condition, state law provided a mandatory, nonwaivable two-week vacation guarantee, but it also provided employees (including associates at law firms) with the right to two additional

\footnotetext{
${ }^{48}$ See Colin Camerer, Prospect Theory in the Wild, in Choices, Values, and Frames 294-95 (Daniel Kahneman and Amos Tversky eds. 2000); Eric Johnson et al., Framing, Probability Distortions, and Insurance Decisions, in id. at 224, 238.

${ }^{49} \mathrm{Id}$.

${ }^{50}$ Id. at $235-38$.

${ }^{51}$ See Sunstein, supra note.

${ }^{52}$ The question asked students to assume that no adverse employment consequences could come from asking for, and receiving, those two extra weeks in vacation. See id.
} 
weeks of vacation, a right that could be "knowingly and voluntarily waived." Hence the second condition was precisely the same as the first, except that the default rule favored the two extra weeks of vacation. In the second condition, students were asked how much employers would have to pay them to give up their right to the two extra weeks. All by itself, the switch in the default rule more than doubled the students' responses, producing a median willingness to accept of $\$ 13,000 .^{53}$

We can imagine countless variations on these experiments. For example, the law might authorize a situation in which employees have to opt into retirement plans, or it might require employers to provide automatic enrollment and allow employees to opt in. Both systems would respect the freedom of employees to choose, and thus either system would be libertarian in that sense. In the same vein, the law might assume that there is no right to be free from age discrimination in employment, permitting employees (through individual negotiation or collective bargaining) to contract for that right -- or it might give employees a nondiscrimination guarantee, subject to waiver via contract. Our suggestion here is that one or another approach is likely to have effects on the choices of employees. This is the sense in which paternalism is inevitable, from government no less than from private institutions.

2. Anchors. In emphasizing the absence of well-formed preferences, we are not speaking only of default rules. Consider the crucial role of "anchors," or starting points, in contingent valuation studies, an influential method of valuing regulatory goods, such as increased safety and environmental protection. ${ }^{54}$ Such studies, used when market valuations are unavailable, attempt to ask people their "willingness to pay" for various regulatory benefits. ${ }^{55}$ Contingent valuation has become prominent in regulatory theory and practice. ${ }^{56}$ Because the goal is to elicit what people actually want, contingent valuation studies are an effort to elicit, rather than to affect, people's values. Paternalism, in the sense of effects on preferences and choices, is not supposed to be part of the picture. But it is extremely difficult for contingent valuation studies to avoid constructing

\footnotetext{
${ }^{53}$ Id.

${ }^{54}$ See, e.g., See Peter Diamond \& Jerry Hausman, Contingent Valuation: Is Some Number Better Than No Number, 8 J. Econ. Persp. 45, 49-52 (1994); Note, Ask A Silly Question, 105 Harv L Rev 1981 (1992); Valuing Environmental Preferences (Ian Bateman \& K. G. Willis eds., 1999).

${ }^{55}$ See id.

${ }^{56}$ See id.
} 
the very values that they are supposed to discover. ${ }^{57}$ The reason is that in the contexts in which such studies are used, people do not have clear or well-formed preferences, and hence it is unclear that people have straightforward "values" that can actually be found. ${ }^{58}$ Hence a form of paternalism verges on the inevitable.

Perhaps the most striking evidence to this effect comes from a study of willingness to pay to reduce annual risks of death and injury in motor vehicles. ${ }^{59}$ The authors attempted to elicit both maximum and minimum willingness to pay for safety improvements. People were presented with a statistical risk and an initial monetary amount, and asked whether they were definitely willing or definitely unwilling to pay that amount to eliminate the risk, or if they were "not sure." If they were definitely willing, the amount displayed was increased until they said that they were definitely unwilling. If they were unsure, the number was moved up and down until people could identify the minimum and maximum.

The authors were not attempting to test the effects of anchors; on the contrary, they were alert to anchoring only because they "had been warned" of a possible problem with their procedure, in which people "might be unduly influenced by the first amount of money that they saw displayed." 60 To solve that problem, the authors allocated people randomly to two subsamples, one with an initial display of 25 pounds, the other with an initial display of 75 pounds. The authors hoped that the anchoring effect would be small, with no significant consequences for minimum and maximum values. But their hope was dashed. For every level of risk, the minimum willingness to pay was higher, with the 75 pound starting point, than the maximum willingness to pay with the 25 pound starting point! $!^{61}$ For example, a reduction in the annual risk of death by 4 in 100,000 produced a maximum willingness to pay of 149 pounds with the 25 pound starting value, but a minimum willingness to pay of 232 pounds with the 75 pound starting value (and a maximum, in that case, of 350 pounds). ${ }^{62}$ The most sensible conclusions are that people

\footnotetext{
${ }^{57}$ See John Payne et al., Measuring Constructed Preferences: Toward a Building Code, 19 J. Risk and Uncertainty 243 (1999).

${ }^{58}$ See id. at $250-53$.

${ }^{59}$ See Michael Jones-Lee and Graham Loomes, Private Values and Public Policy, in Conflict and Tradeoffs in Decision Making 205, 210-212 (Elke Weber et al. eds. 2000).

${ }^{60}$ Id. at 210.

${ }^{61}$ Id. at 211.

${ }^{62}$ Id.
} 
are sometimes uncertain about appropriate values, and whenever they are, anchors have an effect, and sometimes a startlingly large one.

It is not clear how those interested in eliciting (rather than affecting) values might respond to this problem. ${ }^{63}$ What is clear is that in the domains in which contingent valuation studies are used, people often lack well-formed preferences, and starting points have important consequences for behavior and choice.

3. Framing. We have suggested that in the important context of medical decisions, framing effects are substantial. ${ }^{64}$ Apparently most people do not have clear preferences about how to evaluate a procedure that leaves 90 percent of people alive (and 10 percent of people dead) after a period of years. A similar effect has been demonstrated in the important context of obligations to future generations, ${ }^{65}$ a much-disputed policy question. ${ }^{66}$ This question does not directly involve paternalism, because those interested in the valuation of future generations are not attempting to protect people from their own errors. But a regulatory system that attempts to track people's preferences would try to measure intergenerational time preferences, that is, to elicit people's judgments about how to trade off the protection of current lives and future lives. ${ }^{67}$ Hence an important question, asked in many debates about the issue, is whether people actually make such judgments and whether they can be elicited. And indeed, an influential set of studies finds that people value the lives of those in the current generation far more than the lives of those in future generations. ${ }^{68}$ From a series of surveys, Maureen Cropper and her coauthors suggest that people are indifferent between savings one life today and saving 45 lives in 100 years. ${ }^{69}$ They make this suggestion on the basis of questions asking people

\footnotetext{
${ }^{63}$ See Payne et al., supra note, for discussion.

${ }^{64}$ See note supra.

${ }^{65}$ See Shane Frederick, Measuring Intergenerational Time Preference: Are Future Lives Valued Less?, 26 J. Risk and Uncertainty 1 (2003).

${ }^{66}$ Richard Revesz, Environmental Regulation, Cost-Benefit Analysis, and the Discounting of Human Lives, 99 Col L Rev 941 (1999); Comment, Judicial Review of Discount Rates Used in Regulatory CostBenefit Analysis, 65 U Chi L Rev 1333 (1998).

${ }^{67}$ See Revesz, supra note. We are not suggesting that the preferences of current generations are decisive on the policy question.

${ }^{68}$ See Maureen Cropper et al., Rates of Time Preference for Saving Lives, 82 Am. Ewcon. Rev. 469 (1992); Maureen Cropper et al., Preferences for Life Saving Programs: How the Public Discounts Time and Age, 8 J. Risk and Uncertainty 243 (1994).

${ }^{69}$ Id.
} 
whether they would choose a program that saves "100 lives now" or a program that saves a substantially larger number "100 years from now.", 70

But it turns out that other descriptions of the same problem yield significantly different results. ${ }^{71}$ Here, as in other contexts, it is unclear whether people actually have well-formed preferences with which the legal system can work. For example, most people consider "equally bad" a single death from pollution next year and a single death from pollution in 100 years $^{72}$-- implying no preference for members of the current generation. In another finding of no strong preference for the current generation, people are equally divided between two programs: one that will save 55 lives now and 105 more lives in twenty years; and one that will save 100 lives now and 50 lives 25 years from now. ${ }^{73}$ It is even possible to frame the question in such a way as to find that future lives are valued more, not less, highly than current lives. ${ }^{74}$ The most sensible conclusion is that people do not have robust, well-ordered intergenerational time preferences. If so, it is not possible for government to track those preferences, because they are an artifact of how the question is put.

\section{Explanations}

Why, exactly, do default rules, starting points, and framing effects have such large effects? To answer this question, it is important to make some distinctions.

1. Suggestion. In the face of uncertainty about what should be done, people might rely on one of two related heuristics: do what most people do, or do what informed people do. ${ }^{75}$ The default plan or value might be presumed to capture one or the other. In many settings, any starting point will carry some

\footnotetext{
${ }^{70} \mathrm{Id}$.

${ }^{71}$ Frederick, supra note.

${ }^{72}$ Id. at 43.

${ }^{73}$ Id. at 44.

${ }^{74}$ Id. at 45 . Frederick asked subjects to choose between two programs. The first would become more effective over time, saving 100 lives this decade, 200 lives in the following decade, and 300 lives in the decade after that. The second would become less effective over time, saving 300 lives this decade, 200 lives in the following decade, and 100 lives in the decade after that. Most people preferred the first program, apparently suggesting that future lives are valued more highly. Id.

${ }^{75}$ See the discussion of imitation as a fast and frugal heuristic in Joseph Henrich et al., What Is the Role of Culture in Bounded Rationality, in Bounded Rationality: The Adaptive Toolbox 343, 344 (Gerd Gigerenzer and Richard Selten eds.) (2002) ("Cultural transmission capacities allow individuals to shortcut the costs of
} 
informational content and hence will affect choices. Hence if a default rule affects behavior, it might well be because it is taken to carry information about how sensible people usually organize their affairs. Notice that in the context of savings, people might have a mild preference for one or another course, but the preference might be overcome by evidence that most people do not take that course. Some workers might think, for example, that they should not enroll in a 401(k) plan and have a preference not to do so; but the thought and the preference might shift with evidence that the employer has made enrollment automatic. With respect to savings, the designated default plan apparently carries a certain legitimacy for many employees, perhaps because it seems to have resulted from some conscious thought about what makes most sense for most people. ${ }^{76}$ This interpretation is supported by the finding that the largest effects from the new default rule are shown by women and African-Americans. ${ }^{77}$ We might speculate that members of such groups tend to be less confident in their judgments in this domain and perhaps to have less experience in assessing different savings plans.

2. Inertia. A separate explanation points to inertia. ${ }^{78}$ Any change from the default rule or starting value is likely to require some action, and even a trivial action, such as filling in some form and returning it, can leave room for failures due to memory lapses, sloth, and procrastination. Many people wait until the last minute to file their tax return, even though they are getting a refund. The power of inertia should be seen as a form of bounded rationality. Although the costs of switching from the default rule or the starting point can be counted as transactions costs, the fact that large behavioral changes are observed even when such costs are tiny suggests that a purely rational explanation is difficult to accept.

3. Endowment effect. A default rule might create a "pure" endowment effect. It is well known that people tend to value goods more highly if those goods have

search, experimentation, and data processing algorithms, and instead benefit from the cumulative experience stored in the minds (and observed in the behavior) of others.").

${ }^{77}$ See Madrian and Shea, The Power of Suggestion, supra note.

${ }^{77}$ Id. 
been initially allocated to them than if those goods have been initially allocated elsewhere. ${ }^{79}$ And it is well known that in many cases, the default rule will create an endowment effect. ${ }^{80}$ When an endowment effect is involved, the initial allocation, by private or public institutions, affects people's choices simply because it affects their valuations.

4. Ill-formed preferences. In the cases we have discussed, people's preferences are ill-formed and murky. Suppose, for example, that people are presented with various payouts and risk levels for various pension plans. They might be able to understand the presentation; there might be no confusion here. But people might not have a well-defined preference for, or against, a slightly riskier plan with a slightly higher expected value. In these circumstances, their preferences might be endogenous to the default plan simply because they lack well-formed desires that would trump it (whatever it is). In unfamiliar areas, we believe that this situation is common. The range of values in the highway safety study is likely a consequence of the unfamiliarity of the context, which leaves people without clear preferences from which to generate numbers. The effects of framing on intergenerational time preferences attests to the fact that people do not have unambiguous judgments about how to trade off the interests of future generations with those of people now living.

For present purposes, the choice among these various explanations does not greatly matter. The central point is that effects on individual choices are often unavoidable. Of course it is usually good not to block choices, and we do not mean to defend non-libertarian paternalism here. But in an important respect, the anti-paternalistic position is incoherent, simply because there is no way to avoid effects on behavior and choices. The task for the committed libertarian is not to avoid such effects, but to preserve freedom of choice.

Because framing effects are inevitable, it is hopelessly inadequate to say that when people lack relevant information, the best response is to provide it. In order to be effective, any effort to inform people must be rooted in an understanding of how people

\footnotetext{
${ }^{78}$ See id.

${ }^{79}$ See Richard Thaler, Quasi-Rational Economics; Korobkin, supra note.
} 
actually think. Presentation makes a great deal of difference; the behavioral consequences of otherwise identical information depend on how it is framed. In the face of health risks, for example, some presentations of accurate information might actually be counterproductive, because people might attempt to control their fear by refusing to think about the risk at all. In empirical studies, "some messages conveying identical information seemed to work, better than others, and . . some even appeared to backfire." ${ }^{\prime 1}$ When information campaigns fail altogether, it is often because those efforts "result in counterproductive defensive measures," in the form of efforts to reduce cognitive dissonance by not thinking about the relevant hazard. ${ }^{82}$ Hence the most effective approaches go far beyond mere disclosure and combine "a frightening message about the consequences of inaction with an upbeat message about the efficacy of a proposed program of prevention." 83

There are complex and interesting questions here about how to promote welfare. If information greatly increases people's fear, it will to that extent reduce welfare, in part because fear is unpleasant, in part because fear has a range of ripple effects, producing a wide range of social costs. We do not speak to the welfare issue here. Our only suggestions are that if people lack information, a great deal of attention needs to be paid to information-processing, and that without such attention, information disclosure might well prove futile or counterproductive. And to the extent that those who design informational strategies are taking account of how people think, and attempting to steer people in desirable directions, their efforts will inevitably have a paternalistic dimension.

\section{Beyond the Inevitable (But Still Libertarian)}

The inevitability of paternalism is most clear when the planner has to choose starting points, framing effects, or default rules. But if the focus is on welfare, it is reasonable to ask whether the planner should go beyond the inevitable, and whether such a planner can also claim to be libertarian. To illustrate the problem, return to the simple

\footnotetext{
${ }^{80}$ See Kahneman, Knetch, and Thaler, supra note.

${ }^{81}$ Andrew Caplin, Fear as a Policy Instrument 441, 443, in Time and Decision (George Loewenstein et al. eds. 2003).

${ }^{82}$ Id. at 442.
} 
cafeteria example discussed above. Putting the fruit before the desserts is a fairly mild intervention. A more intrusive step would be to place the desserts in another location altogether, so that diners have to get up and get a dessert after they have finished the rest of their meal. This step raises the transactions costs of eating dessert, and according to a standard economic analysis the proposal is quite unattractive--it seems to make dessert eaters worse off and no one better off. But many people face problems of self-control, and these problems lead to health problems, small and large. ${ }^{84}$ Once the costs of selfcontrol are incorporated into the analysis, we can see that some diners would prefer this arrangement, namely those who would eat a dessert if it were put in front of them but would resist temptation if given a little help. To fit with libertarian principles, the planner could arrange two lines in the cafeteria: the tempting line and the non-tempting line. The tempting line would include everything, whereas the non-tempting line would make unhealthy foods less available. Since people could choose either line, this passes the libertarian test. (As a solution to the self-control problem, it might not be entirely adequate, because people would be tempted to join to tempting line.) Hence it is possible to preserve freedom of choice, and to allow opt-outs, but also to favor self-conscious efforts to promote welfare by helping people to solve problems of bounded rationality and bounded self-control. Efforts of this kind need not attempt to provide what people would choose ex ante, even in cases in which preferences exist; but they would nonetheless allow people to move in their preferred directions.

In the domain of employee behavior, there are many imaginable illustrations. Employees might be automatically enrolled in a $405(\mathrm{k})$ plan, with a right to opt out, but employers might require a waiting period, and perhaps a consultation with an adviser, before the opt out could be effective. Thaler and Benartzi have proposed a method of increasing contributions to $401(\mathrm{k})$ plans that also meets the libertarian test. ${ }^{85}$ Under the Save More Tomorrow plan, briefly described in the Introduction, employees are invited to sign up for a program in which their contributions to the savings plan are increased annually whenever they get a raise. Once employees join the plan, they stay in until they

\footnotetext{
${ }^{83}$ Id. at 443.

${ }^{84}$ See Ted O'Donoghue and Matthew Rabin, Studying Optimal Paternalism, As Illustrated by a Model of Sin Taxes, Am. Econ. Rev. (forthcoming 2003); Jolls et al., supra note.
} 
opt out or reach the maximum savings rate in the plan. In the first company to use this plan, the employees who joined increased their savings rates from 3.5 percent to 11.6 percent in a little over two years (three raises). ${ }^{86}$ Very few of the employees who join the plan drop out. We believe that this is successful libertarian paternalism in action. In fact the ideas of automatic enrollment and Save More Tomorrow provide more promising models for increasing savings than recent (and far more expensive) proposals for doing so by decreasing or eliminating taxes on savings. ${ }^{87}$

The same sort of strategy might be used in many domains. Moving from paternalism to protection of third parties, employers (or the state) might seek to increase charitable giving from workers. Is it possible to produce a form of libertarian benevolence, and if so how might this be done? Moral suasion may or may not succeed, but compare a system of Give More Tomorrow. Because workers appear quite willing to depart with a fraction of their future raises, such a system, like Save More Tomorrow, would be highly appealing to many people. In fact the ideas explored here might well be used to produce significant increases in charitable donations (of course there are obvious complexities about institutional design and appropriate default beneficiaries).

It should now be clear that the difference between libertarian and non-libertarian paternalism is not simple and rigid. The libertarian paternalist insists on preserving choice, whereas the non-libertarian paternalist is willing to foreclose choice. But in all cases, a real question is the cost of exercising choice, and here there is a continuum rather than a sharp dichotomy. A libertarian paternalist who is especially enthusiastic about free choice would be inclined to make it relatively costless for people to obtain their preferred outcomes. (Call this a libertarian paternalist.) By contrast, a libertarian paternalist who is especially confident of his welfare judgments would preserve freedom of choice, but would be willing to impose real costs on workers and consumers who seek to do what, in the paternalist's view, would not be in their best interest. (Call this a libertarian paternalist.) Rejecting both routes, a non-libertarian paternalist would attempt to block certain choices. But notice that almost any such attempt will amount, in practice, to an

\footnotetext{
${ }^{85}$ See Richard H. Thalerand Shlomo Benartzi, Save More Tomorrow: Using Behavioral Economics to Increase Employee Saving, Journal of Political Economy (forthcoming).

${ }^{86} \mathrm{Id}$.

${ }^{87}$ See Bush plan (to be added).
} 
effort to impose high costs on those who try to make those choices. Consider a law requiring drivers to wear seat belts. If the law is enforced, and a large fine is imposed, the law is non-libertarian even though determined violators can exercise their freedom of choice - at the expense of the fine. But as the expected fine approaches zero, the law approaches libertarianism. The libertarian paternalism that we are describing and defending here attempts to ensure, as a general rule, that people can easily avoid the paternalist's suggested option. ${ }^{88}$

\section{E. Illustrations and Generalizations}

Many actual and proposed legal provisions embody libertarian paternalism. Some of those provisions require disclosure of information; some of them shift the default rule; some of them preserve freedom of contract but impose procedural or substantive restrictions on those who seek to move in directions that seem, to the planner, to be contrary to their welfare. We divide this brief catalogue into two parts, the first dealing with labor and employment law, and the second dealing with consumers more generally. ${ }^{89}$

1. Labor and employment law. Under the Age Discrimination in Employment Act (ADEA), employees are permitted to waive their rights at the time of retirement, ${ }^{90}$ and hence the statutorily conferred right - to be free from age discrimination - does not reject the libertarian commitment to freedom of contract. But the employee is presumed to have that right unless there has been a "knowing and voluntary" waiver. ${ }^{91}$ To ensure that the waiver is knowing and voluntary, the ADEA imposes a range of procedural hurdles. Thus the waiver must specifically refer "to rights or claims arising under" the ADEA ${ }^{92}$; the employee must be advised in writing to consult with an attorney before executing the agreement $^{93}$; the employee must be given "at least 21 days within which to consider the

\footnotetext{
${ }^{88} \mathrm{We}$ are not, therefore, attempting to enter into the debate between paternalists and antipaternalists, though obviously much of our discussion bears on that debate.

${ }^{89}$ For an overlapping catalogue, see Camerer et al., supra note.

${ }^{90} 29$ USC 626(f)(1) (1994).

${ }^{91}$ Id.

${ }^{92}$ Id $626(f)(1)(B)$.

${ }^{93}$ Id $626(\mathrm{f})(1)(\mathrm{E})$.
} 
agreement" $" 94$; and the agreement must provide for a minimum of a seven day postexecution revocation period..$^{95}$ The ADEA has an unmistakable paternalistic dimension insofar as it switches the default rule to one favoring the employee and also creates a set of procedural barriers to insufficiently informed waivers. At the same time, the ADEA goes beyond inevitable paternalism through those very barriers, which significantly raise the burdens of waiver. But the ADEA preserves freedom of choice and thus satisfies the libertarian criterion.

Labor and employment law offers many other examples. The Model Employment Termination Act alters the standard American rule to the effect that employees may be discharged for no reason or for any reason at all. ${ }^{96}$ Under the Model Act, employees are given the right to be discharged only for cause. ${ }^{97}$ But the Model Act complies with libertarian principles by allowing employers and employees to waive the right on the basis of an agreement, by the employer, to provide a severance payment in the event of a discharge not based on poor job performance. ${ }^{98}$ That payment must consist of one month's salary for every year of employment. This limitation on waiver is substantive and in that sense quite different from the procedural limitation in the ADEA; in that sense it is less libertarian than it might be. But freedom of choice continues to be respected.

2. Consumer protection. In the law of consumer protection, the most obvious examples of libertarian paternalism involve "cooling off" periods for certain decisions. ${ }^{99}$ The underlying rationale is that under the heat of the moment, consumers might make illconsidered or improvident decisions. Both bounded rationality and bounded willpower are the underlying concerns. A mandatory cooling-off period for door-to-door sales, of the sort imposed by the Federal Trade Commission in $1972,{ }^{100}$ is a simple illustration. Hence door-to-door sales must be accompanied by written statements telling buyers of their right to rescind purchases within three days of transactions. ${ }^{101}$ Some states also

${ }^{94} 626(\mathrm{f})(1)(\mathrm{D})(\mathrm{ii})$.

${ }^{95} \operatorname{Id} 626(\mathrm{f})(1)(\mathrm{G})$.

${ }^{96}$ See Model Employment Termination Act, reprinted in Mark A. Rothstein and Lance Liebman, Employment Law 208-19 (3d ed. Statutory Supp. 1997).

${ }^{97}$ Id. at section 4@)

${ }^{98}$ Id.

${ }^{99}$ See the valuable discussion in Camerer et al., supra note.

100 16 CFR 429.1(a) (2001).

${ }^{101}$ Id. 
impose mandatory waiting periods before people may receive a divorce decree. ${ }^{102} \mathrm{We}$ could easily imagine similar restrictions on the decision to marry, and some states have moved in this direction as well. ${ }^{103}$ Aware that people might act impulsively or in a way that they will regret, regulators do not block their choices, but ensure a period for sober reflection. Note in this regard that mandatory cooling-off periods make best sense, and tend to be imposed, when two conditions are met: (1) people are making decisions that they make infrequently and for which they therefore lack a great deal of experience and (2) emotions are likely to be running high. These are the circumstances - of bounded rationality and bounded self-control respectively -- in which consumers are peculiarly prone to making choices that they will regret.

3. Generalizations. We are now in a position to categorize a diverse set of paternalistic interventions: minimal paternalism, coerced choices, procedural constraints, and substantive constraints.

1. Minimal paternalism is that form of paternalism that occurs whenever a planner (private or public) constructs a default rule or starting point with the goal of influencing behavior. So long as it is costless or nearly costless to depart from the default plan, minimal paternalism is maximally libertarian. This is the form of paternalism that we have described as inevitable.

2. Unsure of what choices will promote welfare, a planner might reject default plans or starting points entirely and force people to choose explicitly (what we have described as the strategy of coerced choices). This approach finds an analogue in information-eliciting default rules in contract law, designed to give contracting parties a strong incentive to say what they want. ${ }^{104}$ In a sense, planners who coerce choice are not paternalistic at all. But to the extent that such planners force people to choose whether or not people would like to choose, there is a paternalistic dimension to their actions. ("Choosing is good for both freedom and welfare," they appear to think, whether or not people agree with them.)

${ }^{102}$ See Cal Fam Code 2339 (a); Conn Gen Stat 46b67(a). For general discussion, see Elizabeth Scott, Rational Decisionmaking About Marriage and Divorce, 76 Va L Rev 9 (1990).

${ }^{103}$ See Camerer et al., supra note. 
3. A slightly more aggressive form of paternalism occurs when the default plan is accompanied by procedural constraints, designed to ensure that any departure is fully voluntary and entirely rational. When procedural constraints are in place, it is not costless to depart from the default plan. The extent of the cost, and the aggressiveness of the paternalism, will of course vary with the extent of the constraints. The justification for the constraints will depend on whether there are serious problems of bounded rationality and bounded selfcontrol; if so, the constraints are justified not on the ground that the planner disagrees with people's choices, but because identifiable features of the situation make it likely that choices will be defective. The Age Discrimination in Employment Act is our principal example here.

4. Alternatively, a planner might impose substantive constraints, allowing people to reject the default arrangement, but not on whatever terms they choose. On this approach, the planner selects the terms along which the parties will be permitted to move in their preferred directions. The Model Termination Act and the Fair Labor Standards Act are illustrations. The extent of the departure from libertarianism will be a function of the gap between the legally specified terms and the terms that parties would otherwise reach. Here too the justification for the constraint depends on bounded rationality and bounded self-control.

5. A planner might reject freedom of choice on the ground that those who reject the default plan will err all or almost all of the time. Such a planner will impose significant costs on those who depart from the plan. As we have said, there is a thin line between non-libertarian paternalists and libertarian paternalists who impose high costs, procedural or substantive, on those who reject the plan. Almost all of the time, the non-libertarian paternalist will allow choosers, at some cost, to reject the proposed course of action. Those who are required to wear motorcycle helmets can decide to risk the relevant penalty, and to pay it if need be. Employers and employees might agree to

\footnotetext{
104 See Ian Ayres and Robert Gertner, Filling Gaps in Incomplete Contracts: An Economic Theory of Default Rules, 99 Yale L.J. 87 (1989).
} 
subminimum wage work and risk the penalties if they are caught. In this particular sense, penalties are always prices.

\section{How to Choose: The Toolbox of the Libertarian Paternalist}

How should sensible planners (a category meant to include anyone who must design plans for others, from human resource directors to bureaucrats to kings) choose among possible systems, given that some choice is necessary? We suggest two approaches to this problem. If feasible, a comparison of possible rules should be done using a form of cost-benefit analysis. In many cases, however, such analyses will be both difficult and expensive. As an alternative, we offer some rules of thumb that might be adopted to choose among alternatives. In general, it makes sense to experiment with possible approaches, to identify their results for both choices and outcomes. We have emphasized automatic enrollment plans and Save More Tomorrow because studies have suggested that both of these have a great deal of potential. In other domains, plans are likely to be proposed in the face of highly imperfect information; more data will reveal a great deal. Large-scale programs are most justified if repeated experiments have shown that they actually work.

\section{A. Costs and Benefits}

The goal of a cost-benefit study would be to measure the full ramifications of any design choice. In the context at hand, the cost-benefit study cannot be based on willingness to pay (WTP), because WTP will be a function of the default rule. ${ }^{105}$ It must be a more open-ended (and inevitably somewhat subjective) assessment of the values at stake. To illustrate, take the example of automatic enrollment. Under automatic enrollment, some employees will join the plan who otherwise would not. Presumably, some are made better off (especially if there is an employer match) but some may be made worse off (e.g., those who are highly liquidity constrained). A cost-benefit analysis would attempt to evaluate these gains and losses.

\footnotetext{
${ }^{105}$ See Kahneman, Knetsch, and Thaler, supra note; Korobkin, supra note.
} 
If the issue were only enrollment, we think it highly likely that the gains would exceed the losses. Because of the right to opt out, those who need the money immediately are able to have it. And in the abstract, it is reasonable to believe that the costs of having too little saved up for retirement are typically greater than the costs of having saved too much. Few people find that their welfare has been substantially diminished by excessive savings. Empirical studies find that revealed choices do not undermine but support this judgment. Most employees do join the plan eventually, and very few who are automatically enrolled opt out when they figure out what has happened to them. ${ }^{106}$ It would be possible to respond that our reliance on behavior as an indication of welfare is inconsistent with one of the central claims of this Article, to the effect that choices do not necessarily coincide with welfare. But there is no inconsistency. Compare rules calling for mandatory cooling off periods. The premise of such rules is that people are more likely to make good choices when they have had time to think carefully and without a salesperson present. Similarly, it is reasonable to think that if, on reflection, workers realized that they had been "tricked" into saving too much, they might take the effort to opt out. The fact that very few participants choose to opt out supports (though it does not prove) the claim that they are helped by a system that makes joining easy.

Once the other effects of automatic enrollment are included, the analysis becomes cloudier. Any plan for automatic enrollment must include a specified default savings rate. Some of those automatically enrolled at a three percent savings rate -- a typical default in automatic enrollment -- would have chosen a higher rate if left to their own devices. ${ }^{107}$ If automatic enrollment leads some or many people to save at a lower rate than they would choose, the plan might be objectionable for that reason. Hence we are less confident that this more complete cost-benefit analysis would support the particular opt-out system, though a higher savings rate might well do so, and a more sophisticated plan, avoiding some of these pitfalls, is discussed below.

Similar trade-offs are involved with another important issue: The appropriate default rule for organ donations. In many nations -- Austria, Belgium, Denmark, Finland, France, Italy, Luxemburg, Norway, Singapore, Slovenia, and Spain -- people are

\footnotetext{
${ }^{106}$ See Madrian and Shea, supra note; Choi et al., supra note.

${ }^{107}$ See id.
} 
presumed to consent to allow their organs to be used, after death, for the benefit of others; but they are permitted to rebut the presumption, usually through an explicit notation to that effect on their drivers' licenses. ${ }^{108}$ In the United States, by contrast, those who want their organs to be available for others must affirmatively say so, also through an explicit notation on their drivers' licenses. The result is that in "presumed consent" nations over 90 percent of people make their organs available for donation, whereas in the United States, the corresponding number is below 20 percent. ${ }^{109}$ We hypothesize that this dramatic difference is not a product of deep cultural differences, but of the massive effect of the default rule. Hence we would predict that a European-style default rule, in the United States, would produce European-level donation rates.

The default rules for organ donation do not fit the usual definition of paternalism. The issue is the welfare of third parties, not of choosers. Here we are speaking not of libertarian paternalism, but of libertarian benevolence: An approach that attempts to promote benevolence, and to assist vulnerable people, without mandating behavior in any way. We suggest that changes in default rules, or a system of Give More Tomorrow, could produce large increases in public assistance - and that such approaches could do so in a way that avoids coercion. With respect to behavior, the analysis of libertarian benevolence is quite similar to that of libertarian paternalism. One of the advantages of that analysis is the demonstration that when third party interests are at stake, the default rule will matter a great deal. It follows that planners can often deliver significant benefits to third parties not by coercing choice, but by switching the default rule. In the case of organ donation, this is what we observe.

Does one or another default rule promote welfare? At first glance, the European rule seems much better, simply because it should save a large number of lives without compromising any other important value. The most that can be said against the European rule is that through inertia, perceived social pressure, or confusion, some people might end up donating their organs when they would not, all things considered, prefer to do so ex ante. (Their ex post preferences are difficult to infer!) If this objection (or some

\footnotetext{
${ }^{108}$ See http://www.presumedconsent.org.futuresite.register.com/ ${ }^{109}$ Id.
} 
other ${ }^{110}$ ) seems forceful, an alternative would be to adopt the coerced choice approach to require, at the time of applying for a driver's license, that applicants indicate whether they want to allow their organs to be used for the benefit of others. We make only two claims about this example. First, the evaluative question turns in large part on empirical issues, of the sort that it would be both possible and useful to investigate. Second, the American approach is unlikely to be best. ${ }^{111}$

\section{B. Rules of Thumb}

In many cases, the planner will be unable to make a direct inquiry into welfare, either because too little information is available, or because the costs of doing the analysis are not warranted. The committed anti-paternalist might say, in such cases, that people should simply be permitted to choose as they see fit. We hope that we have said enough to show why this response is unhelpful. What people choose often depends on the starting point, and hence the starting point cannot be selected by asking what people choose. In these circumstances, the libertarian paternalist would seek indirect proxies for welfare - methods that test whether one or another approach promotes welfare without relying on unreliable guesswork about that question. We suggest three possible methods.

First, the libertarian paternalist might select the approach that the majority would choose if explicit choices were required and revealed. In the context of contract law, this is the most familiar inquiry in the selection of default rules ${ }^{112}$ - provisions that govern contractual arrangements in the absence of express provision by the parties. Useful though it is, this market-mimicking approach raises its own problems. Perhaps the majority's choices would be insufficiently informed, or a reflection of bounded rationality or bounded self-control. Perhaps those choices would not, in fact, promote the majority's welfare. At least as a presumption, however, it makes sense to follow those

\footnotetext{
${ }^{110}$ It is conceivable that the care of fatally ill patients might be sacrificed in order to harvest their organs, but no evidence suggests that this is a serious risk.

${ }^{111}$ It follows from this example that if private or public planners would like to increase charitable donations, they could easily do that simply by creating automatic deductions for charity. Even if workers are allowed to opt out, clever planners should easily be able to ensure a much higher level of donations. Compare the system of automatic-donations-with-opt-out to official churches in various nations in Europe (citations to be added).

${ }^{112}$ See, e.g., Ian Ayres and Robert Gertner, supra note.
} 
choices if the planner knows what they would be. A deeper problem is that the majority's choices might themselves be a function of the starting point or the default rule. If so, the problem of circularity dooms the market-mimicking approach. But in some cases, at least, the majority might go one way or the other regardless of the starting point; and to that extent, the market-mimicking strategy is workable. Recall that in the cafeteria example, some options would not fit with the majority's ex ante choices (hot asparagus pie, peanut butter soup), and that for savings, some allocations would certainly violate the choices of ordinary workers (say, an allocation of 30 percent or more to savings). In fact a clear understanding of majority choices might well support a default rule that respects those choices even if the planner thinks that an inquiry into welfare would support another rule. At the very least, planners should be required to have real confidence in their judgment if they seek to do something other than what a suitably informed majority would find to be in its interest.

Second, the libertarian paternalist might select the approach that we have called coerced choices, one that would force people to make their choices explicit. This approach might be chosen if the market-mimicking strategy fails, either because of the circularity problem or because the planner does not know which approach would in fact be chosen by the majority. We have seen the possibility of forced choices in the context of retirement plans and organ donations; it would be easy to multiply examples. In the law of contract, courts sometimes choose "penalty defaults" - default rules that penalize the party in the best position to obtain a clear statement on the question at hand, and hence create an incentive for clarity for the person who is in the best position to produce clarity. ${ }^{113}$ Libertarian paternalists might go along the same track; in fact penalty defaults can be seen as a form of libertarian paternalism.

Here too, however, there is a risk that the choices that are actually elicited will be inadequately informed or will not promote welfare. In the case of retirement plans, for example, forced choices have been found to produce higher participation rates than requiring opt-ins, but lower rates than requiring opt-outs. ${ }^{114}$ If it is likely that automatic enrollment promotes people's welfare, perhaps automatic enrollment should be preferred

\footnotetext{
${ }^{113}$ See id.

${ }^{114}$ See Choi et al.., supra.
} 
over forced choices. The only suggestion is that where social planners are unsure how to handle the welfare question, they might devise a strategy that requires people to choose.

Third, the libertarian paternalist might select the approach that minimizes the number of opt-outs. Suppose, for example, that when drivers are presumed to want to donate their organs to others, only 10 percent opt out - but that when drivers are required to signal their willingness to donate their organs to others, 30 percent opt in. This is an ex post inquiry into people's preferences, in contrast to the ex ante approach favored by the market-mimicking strategy. With those numbers, there is reason to think that the presumption in favor of organ donation is better, if only because more people are sufficiently satisfied to leave it in place.

\section{How Much Choice Should Be Offered?}

Sweden recently adopted a partial privatization of its social security system along similar lines to those now being suggested in the United States: 2.5 percent of the payroll tax is invested in individual accounts. ${ }^{115}$ The designers of this plan made two decisions that we think would draw the approval of most anti-paternalists. First, all money managers that met certain fiduciary conditions were permitted to have their funds be included among those offered to participants. ${ }^{116}$ Second, although a default investment portfolio was designated for those participants who did not select one for themselves, participants were urged (via a massive publicity campaign) to eschew the default and instead to select their own portfolios. ${ }^{117}$ As a result of these two choices, there were over 450 funds in the plan, and very few Swedes selected the default option. ${ }^{118}$ It is too soon to judge how well the participants did at choosing their portfolios, but we do know that the largest market share (about 5 percent) was invested in a fund that invested primarily in Internet stocks. ${ }^{119}$

115 See Goran Normann and Daniel J. Mitchell, Pension Reform in Sweden: Lessons for American Policymakers (2002), available at http://www.heritage.org/Research/SocialSecurity/bg1381es.cfm

${ }_{117}^{116}$ See http://www.nek.uu.se/Pdf/wp2002_6.pdf

${ }^{117} \mathrm{Id}$.

${ }^{118}$ See http://www.nek.uu.se/Pdf/wp2002_6.pdf

${ }^{119}$ Id. 
We outline the Swedish experience to illustrate a more general question. How much choice should people be given? Libertarian paternalists want to promote freedom of choice, but they need not seek to provide bad options, and among the set of reasonable ones, they need not argue that more is necessarily better. Indeed that argument is quite implausible in many contexts. With respect to savings plans, would hundreds of thousands of options be helpful? Millions? Thirty years ago, most academics had only two investment options in their retirement plan, TIAA and CREF. Now most universities offer more than one provider and often dozens, if not hundreds, of funds from which to choose. Some of the relevant plans, designed to be readily intelligible, seem impossibly complicated even to moderately well-informed academics (one of us speaks from personal experience). Do participants gain from this increase in their choice set? In a standard economic analysis this is a non-question. It is a basic axiom of rational choice theory that more choices cannot make people worse off (at least abstracting from the costs of making the decision). But a complete analysis, informed by the research on the psychology of decision making, is more complicated. It is certainly possible that 450 is more than the optimal number of funds to offer in a system of individual accounts. Indeed, one recent study finds that when 401(k) plans offer more choice, participants are slower to join, perhaps because they are overwhelmed by the number of choices and procrastinate. $^{120}$

It is far beyond our ambition here to venture a full analysis of the question how much choice to offer individuals in various domains. ${ }^{121}$ Instead, we identify some questions that a libertarian paternalist might ask to help decide how much (reasonable) choice to offer. Two general considerations are relevant: the costs of decisions and the costs of errors. When a number of options increases the costs of decisions, there is reason to reduce the number of options -- a reason that might be overcome if that number makes it more likely that people will make choices that increase their welfare. It follows that numerous options are more likely to be preferred if they will lead to welfare-promoting

\footnotetext{
${ }^{120}$ See How Much Choice Is Too Much?: Determinants of individual contributions in 401(k) retirement plans? Sheena S. Iyengar, Wei Jiang, and Gur Huberman, unpublished working paper, Columbia Business School, 2003.

${ }^{121}$ For relevant discussion, see George Loewenstein, Costs and Benefits of Health- and Retirement-Related Choice, in Social Security and Medicare: Individual vs. Collective Risk and Responsibility (Sheila Burke et al. eds. 2000); Gerald Dworkin, Is More Choice Better Than Less?, in Gerald Dworkin, Autonomy (1988).
} 
decisions for many or most (and hence reduce error costs). The more particular questions we introduce are a way of specifying the inquiry into decision costs and error costs. Our analysis is directly relevant to debates about retirement plans and the privatization of social security; in the latter context, it raises doubts about the idea that workers would benefit from an extremely wide range of choices. ${ }^{122}$

1. Do choosers have informed preferences? In some domains, consumers and workers are highly informed - so much so that they will not even be influenced by default rules. Most adults have experimented enough over the course of their lives to have a good sense of what flavors of ice cream they like. They can do a decent job of picking even in a shop offering dozens of flavors. If the default option is asparagusflavored ice cream, they will be unlikely to choose it, and might well be annoyed. But when faced with a menu listing many unfamiliar foods in a foreign country, people might not be benefited by being asked to choose among them, and they might prefer a small list or ask the waiter for a default suggestion (e.g., what do other tourists like?). Clever restaurants catering to tourists often offer a default "tourist menu." Many actual choices fall between the poles of ice cream flavors and foreign menus. When information is limited, countless options increase the costs of decisions without increasing the likelihood of accuracy. But when choosers are highly informed, numerous options decrease the likelihood of error and do not greatly increase decision costs, simply because informed choosers can more easily navigate the menu of options.

2. Is the mapping from options to preferences transparent? If we order a coffee ice cream cone, we have a pretty good idea what we will consume. If we invest $\$ 10,000$ in a mix of mutual funds, we have little idea (without the aid of sophisticated software) what a change in the portfolio will do to our distribution of expected returns in retirement. When we choose between health plans, we may not fully understand all the ramifications of our choice. If I get a rare disease, will I be able to see a good specialist? How long will I have to wait in line? When people have a hard time predicting how their choices will end up affecting their lives, they have less to gain by numerous options and perhaps even by choosing for themselves. If it is hard to map from options to preferences,

$\overline{{ }^{122} \text { See also Loewenstein, supra note. }}$ 
a large set of choices is likely to be cognitively overwhelming, and thus to increase the costs of decisions without also increasing welfare by reducing errors.

3. How much do preferences vary across individuals? Some people smoke; others hate the smell of smoke. Some people like hard mattresses; others like soft ones. How do hotels deal with this problem? Most choose to cater to differences in tastes with respect to smoking but not with respect to mattresses. The mattress that appeals to the median hotel guest seems to be good enough to satisfy most customers, but the threat of a smoky room (or a night without cigarettes) is enough to scare customers away. Here is a case in which many people have well-formed preferences that trump default rules. Many planners, both private and public, must make similar tradeoffs. Since offering choice is costly, sensible planners make multiple choices available when people's preferences vary most. The argument for a large option set is thus strongest in cases of preferences that are both clear and heterogeneous. In such cases, people's welfare is likely to be promoted if each can choose as he sees fit, and homogeneity will lead to inaccuracy and thus widespread error costs.

4. Do consumers value choosing for themselves, per se? Freedom of choice is itself an ingredient in welfare. In some situations people derive welfare from the very act of choosing. But sometimes it is a chore to have to choose, ${ }^{123}$ and the relevant taste can differ across individuals. (One of us derives pleasure from reading and choosing from a wine list, the other finds that enterprise basically intolerable. ${ }^{124}$ ) The point very much bears on the decision whether to force explicit choices or instead to adopt a default rule that reflects what the majority wants. If making choices is itself a subjective good, the argument for forced choices is strengthened. But much of the time, especially in technical areas, people do not particularly enjoy the process of choice, and a large number of options is a burden. By contrast, a thoughtfully chosen default rule, steering them in sensible directions, is a blessing.

\footnotetext{
123 Hence the association between choice and welfare is doubly contingent: Choice may or may not promote welfare, and choice may or may not be an ingredient in welfare. We are putting to one side the association between freedom of choice and autonomy, see note supra, and focussing here on the number of options to be provided.
} 


\section{Objections}

The argument for libertarian paternalism seems compelling to us, even obvious, but we suspect that hard-line anti-paternalists, and possibly others, will have objections. We respond to three possible objections here.

The first objection is that by advocating libertarian paternalism, we are starting down a very slippery slope. Once one grants the possibility that default rules for savings or cafeteria lines should be designed paternalistically, it might seem impossible to resist highly non-libertarian interventions. Critics might envisage an onslaught of what seem, to them, to be unacceptably intrusive forms of paternalism, from requiring motorcycle riders to wear helmets to mandatory waiting periods before consumer purchases to bans on cigarette smoking to intrusive health care reforms of many imaginable kinds. In the face of the risk of overreaching, might it not be better to avoid starting down the slope at all?

There are three responses. First, in many cases there is simply no viable alternative to paternalism in the weak sense, and hence planners are forced to take a least a few tiny steps down that slope. Recall that paternalism, in the form of effects on behavior, is frequently inevitable. In such cases, the slope cannot be avoided. Second, the libertarian condition, requiring opt-out rights, sharply limits the steepness of the slope. So long as paternalistic interventions can be easily avoided by those who seek to adopt a course of their own, the risks emphasized by anti-paternalists are minimal. Third, those who make the slippery slope argument are acknowledging the existence of a self-control problem, at least for planners. But if planners, including bureaucrats and human resource managers, suffer from self-control problems, then it is highly likely that other people do too. $^{125}$

A second and different sort of objection is based on a deep mistrust of the ability of the planner (especially the planner working for government) to make sensible choices. Even those who normally believe that everyone chooses rationally treat with deep skepticism any proposal that seems to hinge on rational choices by bureaucrats. Part of

\footnotetext{
${ }^{124}$ A more serious example comes from evidence that many patients do not want to make complex medical decisions and would prefer their doctors to choose for them. See Carl Schneider, The Practice of Autonomy (1998).
} 
the skepticism is based on a belief that bureaucrats lack the discipline imposed by market pressures; part of it is rooted in the fear that well-organized private groups will move bureaucrats in their preferred directions. We happily grant that planners are human, ${ }^{126}$ and thus are both boundedly rational and subject to the influence of objectionable pressures. Nevertheless, as we have stressed, these human planners are sometimes forced to make choices, and it is surely better to have them trying to improve people's welfare rather than the opposite. In emphasizing the important effect of plan design on choice (a point underappreciated by economists, lawyers, and planners), we hope to encourage plan designers to become more informed. And by arguing for a libertarian check on bad plans, we hope to create a strong safeguard against ill-considered or ill-motivated plans.

A third objection would come from the opposite direction. Enthusiastic paternalists, emboldened by evidence of bounded rationality and self-control problems, might urge that in many domains, the libertarian position is quite implausible. At least if the focus is entirely or mostly on welfare, it might seem clear that in certain circumstances, people should not be given freedom of choice, for the simple reason that they will choose poorly. In those circumstances, why should anyone insist on libertarian paternalism, as opposed to unqualified or nonlibertarian paternalism?

This objection raises complex issues of both value and fact, and we do not intend to venture into difficult philosophical territory here. ${ }^{127}$ Our basic response is threefold. First, we reiterate our understanding that planners are human, and so the real comparison is between boundedly rational choosers with self-control problems and boundedly rational planners facing self-control problems of their own. ${ }^{128}$ It is doubtful that the comparison can sensibly be made in the abstract. Second, an opt-out right operates as a safeguard against confused or improperly motivated planners, and in many contexts, that safeguard is crucial even if it potentially creates harm as well. Third, nothing we have said denies the possibility that in some circumstances, it makes best sense to impose significant costs on those who reject the proposed course of action, or even to deny freedom of choice altogether. Indeed, the discussion in Part V can easily be developed

\footnotetext{
${ }^{125} \mathrm{We}$ acknowledge that bureaucrats might be subject to distinctive pressures that aggravate self-control problems.

${ }^{126}$ See Jolls, supra note, at 1543.

${ }^{127}$ See Dworkin, supra note, for discussion.
} 
into an account of what those circumstances are likely to be. The factors identified there might well be taken as a basis for deciding whether and when to block choices. Our only qualification is that when third party effects are not present, the general presumption should be in favor of freedom of choice, and that presumption should be rebutted only when individual choice is demonstrably inconsistent with individual welfare. ${ }^{129}$

\section{Conclusion}

Our goal here has been to describe and to defend libertarian paternalism - an approach that preserves freedom of choice but that authorizes both private and public institutions to steer people in directions that will promote their welfare. Some kind of paternalism is likely whenever such institutions set out arrangements that prevail unless people affirmatively choose otherwise. Our central empirical claim has been that in many domains, people's preferences are labile and ill-formed, and hence starting points and default rules are likely to be quite sticky. In these circumstances, the goal should be to avoid random, inadvertent, arbitrary, or harmful effects and to produce a situation that is likely to promote people's welfare, suitably defined. Indeed, many current social outcomes are, we believe, both random or inadvertent, in the sense that they are a product of default rules whose behavior-shaping effects have never been a product of serious reflection.

When the direct welfare inquiry is too hard to handle, libertarian paternalists have a range of alternatives. They might, for example, select an approach that would be sought by the majority, that requires or promotes explicit choices, or that minimizes opt-outs. We have also identified the factors that make it most sensible to increase the range of options, in an effort to show that the relationship between choice and welfare presents tractable empirical questions, and should not be resolved by dogmas, a priori arguments, and definitions. In our view, libertarian paternalism is not only a conceptual possibility; it also provides a foundation for rethinking many areas of private and public law.

\footnotetext{
${ }^{128}$ See the discussion of behavioral bureaucrats in Jolls et al., supra note, at 1543-45.

${ }^{129}$ This is a necessary condition, not a sufficient one; believers in autonomy will not agree that welfarist concerns override freedom of choice. We do not attempt to speak to the underlying debates here; libertarian
} 
Readers with comments may address them to:

Cass R. Sunstein

University of Chicago Law School

1111 East 60th Street

Chicago, IL 60637

csunstei@midway.uchicago.edu

paternalists need not take a stand on the competing positions. For relevant discussion, see Dworkin, supra note. 


\section{University of Chicago Law School}

\section{Public Law and Legal Theory Working Paper Series}

1. Cass R. Sunstein and Edna Ullmann-Margalit, Second-Order Decisions (November 1999; Ethics, v. 110, no. 1).

2. Joseph Isenbergh, Impeachment and Presidential Immunity from Judicial Process (November 1999; forthcoming Yale Law and Policy Review v.18 \#1).

3. Cass R. Sunstein, Is the Clean Air Act Unconstitutional? (August 1999; Michigan Law Review \#3).

4. Elizabeth Garrett, The Law and Economics of "Informed Voter" Ballot Notations (November 1999, University of Virginia Law Review, v. 85).

5. David A. Strauss, Do Constitutional Amendments Matter? (November 1999)

6. Cass R. Sunstein, Standing for Animals (November 1999)

7. Cass R. Sunstein, Culture and Government Money: A Guide for the Perplexed (April 2000).

8. Emily Buss, Without Peers? The Blind Spot in the Debate over How to Allocate Educational Control between Parent and State (April 2000).

9. David A. Strauss, Common Law, Common Ground, and Jefferson's Principle (June 2000).

10. Curtis A. Bradley and Jack L. Goldsmith, Treaties, Human Rights, and Conditional Consent (May 2000; Pennsylvania Law Review v. 149).

11. Mary Ann Case, Lessons for the Future of Affirmative Action from the Past of the Religion Clauses? (May 2001, Supreme Court Review, 2000)

12. Cass R. Sunstein, Social and Economic Rights? Lessons from South Africa (May, 2000).

13. Jill Elaine Hasday, Parenthood Divided: A Legal History of the Bifurcated Law of Parental Relations

14. Elizabeth Garrett, Institutional Lessons from the 2000 Presidential Election (May 2001).

15. Richard A. Epstein, The Allocation of the Commons: Parking and Stopping on the Commons (August 2001).

16. Jack Goldsmith, The Internet and the Legitimacy of Remote Cross-Border Searches (October 2001).

17. Adrian Vermeule, Does Commerce Clause Review Have Perverse Effects? (October 2001).

18. Cass R. Sunstein, Of Artificial Intelligence and Legal Reasoning (November 2001).

19. Elizabeth Garrett, The Future of Campaign Finance Reform Laws in the Courts and in Congress, The William J. Brennan Lecture in Constitutional Law (December 2001).

20. Julie Roin, Taxation without Coordination (March 2002).

21. Geoffrey R. Stone, Above the Law: Research Methods, Ethics, and the Law of Privilege (March 2002; forthcoming J. Sociological Methodology 2002).

22. Cass R. Sunstein, Is There a Constitutional Right to Clone? (March 2002). 
23. Emily Buss, Parental Rights (May 2002, forthcoming Virginia Law Review).

24. David A. Strauss, Must Like Cases Be Treated Alike? (May 2002).

25. David A. Strauss, The Common Law Genius of the Warren Court (May 2002).

26. Jack Goldsmith and Ryan Goodman, U.S. Civil Litigation and International Terrorism (June 2002).

27. Jack Goldsmith and Cass R. Sunstein, Military Tribunals and Legal Culture: What a Difference Sixty Years Makes (June 2002).

28. Cass R. Sunstein and Adrian Vermeule, Interpretation and Institutions (July 2002).

29. Elizabeth Garrett, Is the Party Over? The Court and the Political Process (August 2002).

30. Cass R. Sunstein, The Rights of Animals: A Very Short Primer (August 2002).

31. Joseph Isenbergh, Activists Vote Twice (November 2002).

32. Julie Roin, Truth in Government: Beyond the Tax Expenditure Budget (November 2002).

33. Cass R. Sunstein, Hazardous Heuristics (November 2002).

34. Cass R. Sunstein, Conformity and Dissent (November 2002).

35. Jill Elaine Hasday, The Principle and Practice of Women's "Full Citizenship": A Case Study of Sex-Segregated Public Education (December 2002).

36. Cass R. Sunstein, Why Does the American Constitution Lack Social and Economic Guarantees? (January 2003).

37. Adrian Vermeule, Mead in the Trenches (January 2003).

38. Cass R. Sunstein, Beyond the Precautionary Principle (January 2003).

39. Adrian Vermeule, The Constitutional Law of Congressional Procedure (February 2003).

40. Eric A. Posner and Adrian Vermeule, Transitional Justice as Ordinary Justice (March 2003).

41. Emily Buss, Children's Associational Rights? Why Less Is More (March 2003)

42. Emily Buss, The Speech Enhancing Effect of Internet Regulation (March 2003)

43. Cass R. Sunstein and Richard H. Thaler, Libertarian Paternalism Is Not an Oxymoron (May 2003)

44. Elizabeth Garrett, Legislating Chevron (April 2003)

45. Eric A. Posner, Transfer Regulations and Cost-Effectiveness Analysis (April 2003)

46. Mary Ann Case, Developing a Taste for Not Being Discriminated Against (May 2003) 